\title{
Development of a water-soluble 3-formylBODIPY dye for fluorogenic sensing and cell imaging of sulfur dioxide derivatives
}

\author{
Murat Işık ${ }^{\mathrm{a}, *}$, Ilke Simsek Turan ${ }^{\mathrm{b}}$, Suay Dartar ${ }^{\mathrm{c}}$ \\ ${ }^{a}$ Department of Food Engineering, Bingöl University, Bingöl 12000, Turkey \\ ${ }^{\mathrm{b}}$ UNAM-National Nanotechnology Research Center, Bilkent University, Ankara 06800, Turkey \\ ${ }^{\mathrm{c}}$ Department of Chemistry, Faculty of Science, Izmir Institute of Technology, Urla 35430, Izmir, Turkey
}

\section{A R T I C L E I N F O}

\section{Article history:}

Received 25 February 2019

Revised 15 April 2019

Accepted 24 April 2019

Available online 25 April 2019

This work is dedicated to the memory of our beloved mentor, Prof. Dr. İdris Mecidoğlu Akhmedov, who recently passed away.

Keywords:

Fluorogenic probes

BODIPY dyes

Water-soluble fluorophores

Sulfur dioxide derivatives

\begin{abstract}
A B S T R A C T
A new water-soluble, highly fluorogenic 3-formylBODIPY dye that enables the sensing of $\mathrm{SO}_{2}$ derivatives in aqueous buffers and cancer cells is reported. The quaternary ammonium group appended through the meso-position of the BODIPY dye ensures water solubility. The probe exhibits high specificity for cytosolic (bi)sulfites and fluoresces brightly in human lung adenocarcinoma cells (A549).
\end{abstract}

() 2019 Elsevier Ltd. All rights reserved.
The fluorogenic sensing and signalling of biologically relevant small molecules, with a major emphasis on sulfur-containing ones, has drawn significant attention [1]. Being both a well-known air pollutant and a common food additive (E220-228), sulfur dioxide $\left(\mathrm{SO}_{2}\right)$, has been the focus of many recent works [2]. Once hydrated, it is transformed into a pH-dependent equilibrium mixture of sulfite, bisulfite and/or sulfur dioxide species $\left(\mathrm{SO}_{3}^{2-}, \mathrm{HSO}_{3}^{-}\right.$and/or $\left.\mathrm{SO}_{2}\right)$, all of which are collectively called sulfites or sulfiting agents, and have found extensive use as preservatives in food processing for more than a century [3]. The wine industry, for example, relies heavily on sulfites to improve/maintain the sensory characteristics of end-products, such as taste, aroma, and color [4]. Exposure to high doses of sulfites, on the other hand, is associated with a number of diseases such as allergic asthma, urticarial dermatitis, hypotension, abdominal pain, lung cancer, and neurological disorders [5]. At some extremes, it is even known to kill individuals who are hypersensitive to sulfites [5]. Consequently, the use of sulfites as antimicrobial agents/food additives is restricted by international legislation (upper limit $=0.7 \mathrm{mgkg}^{-1}$ of body weight; World Health Organisation - WHO) [3]. Additionally, sulfur dioxide is known to be endogenously produced in living organisms via the metabolic

\footnotetext{
* Corresponding author.

E-mail address: misik@bingol.edu.tr (M. Işık).
}

degradation of biological thiols (e.g. cysteine and glutathione) [6]. As such, recent reports have revealed vasodilatation activities of $\mathrm{SO}_{2}$, and thereby suggest its role as a gasotransmitter [7]. Nevertheless, its precise physiological roles remain largely unknown [2]. Considered together, the sensing and quantification of sulfites in samples of foods/beverages or in biological matrices is of considerable interest.

Early methods for the detection of sulfites include titration (first oxidation by hydrogen peroxide to sulfuric acid, then titration with sodium hydroxide) [8], electrochemistry [9], capillary electrophoresis [10], spectrofluorometry [11], and colorimetry [12]. However, these methods generally require pretreatment of the samples, i.e. extraction or bleaching, which often retards the analysis to hours.

Fluorogenic sensing methods, present excellent opportunities due to their unique attributes, such as operational simplicity, inherent high sensitivity, and ready availability of fluorescence spectrometers; more importantly, fluorogenic probes make in vivo imaging possible [13]. The design of fluorescent probes relies largely on reaction-based sensing platforms [14], which take advantage of the nucleophilicity of the sulfur atom of sulfiting agents. Several sulfite-reactive functional groups (Michael type acceptors [15], levulinate esters [16], aldehydes [17], and others [18]) have been installed on fluorophores to create a sensing event, 
among which, protocols involving conjugate addition are by far the most frequent. Early examples of sulfite probes, however, have required the use of an organic co-solvent [16b,17c], long incubation times (up to 1 day) [18d], UV excitation [18a], and exhibited low fluorescence enhancement often with nonspecific side reactions, which limit their practical applications. Therefore, to avoid the above-listed weaknesses of these precedents, the last couple of years have witnessed a number of papers on the fluorogenic sensing of sulfites [15-18].

Building on our previous efforts in this area [19], herein we wish to describe new water-soluble 2-/3-formyl-BODIPY dyes (Fig. 1). BODIPY (boron-dipyrromethene) dyes were explored because of their highly desirable characteristics, such as narrow emission bands, rich functionalization chemistry, high molar absorptivity and quantum yields, no pH dependency and operation in the visible spectral range [20]. These dyes, once judiciously designed, allow control over the fluorescence emission intensity through photoinduced electron transfer (PeT) and/or internal charge transfer (ICT) photophysical processes [21]. BODIPY dyes find use in a number of applications such as fluorescent probes/ labels [22], dye sensitized organic solar cells [23], and photodynamic therapy [24], among many others [25].

Their insolubility in water, however, impedes potential applications in aqueous media. They typically tend to form non-fluorescent aggregates, unless a water-solubilizing auxiliary group is attached $[19,26]$. Encouraged by parallel efforts of the Ziessel group [26f], we have introduced water-solubilizing (zwitter)ionic quaternary ammonium units through the meso- (or 8-) position of the BODIPY core to make them water-soluble. The reactivity with sulfite was ensured by conjugating the fluorophore with formyl units through the 2- and 3-positions of the BODIPY core. We hypothesized that, upon reaction with sulfites, the $\pi$-conjugation between the BODIPY core and the formyl unit would be broken, which resultantly may by-pass an ICT quenching process and induce a change in fluorescence emissions.

Therefore, we synthesized 4-((dimethylamino)methyl)benzaldehyde, a common starting material for all probe candidates 1-4, using a three-step patent procedure [27]. In addition, we tried a one-step synthesis of this aldehyde by direct reductive amination of terephthalaldehyde; the strategy worked but with low chemical yields (8-11\%, see ESI). Classical BODIPY dye synthesis conditions, for which catalytic amounts of trifluoroacetic acid (TFA) is generally sufficient, failed to give intermediate products $\mathbf{5}$ and $\mathbf{6}$ in our hands (Scheme 1). We reasoned that the benzylic amino group of the dye buffers the TFA used, thus inhibiting the condensation reaction of the aldehyde with the pyrroles. As a result, one equivalent of TFA was necessary to afford BODIPYs $\mathbf{5}$ and $\mathbf{6}$ in reasonable

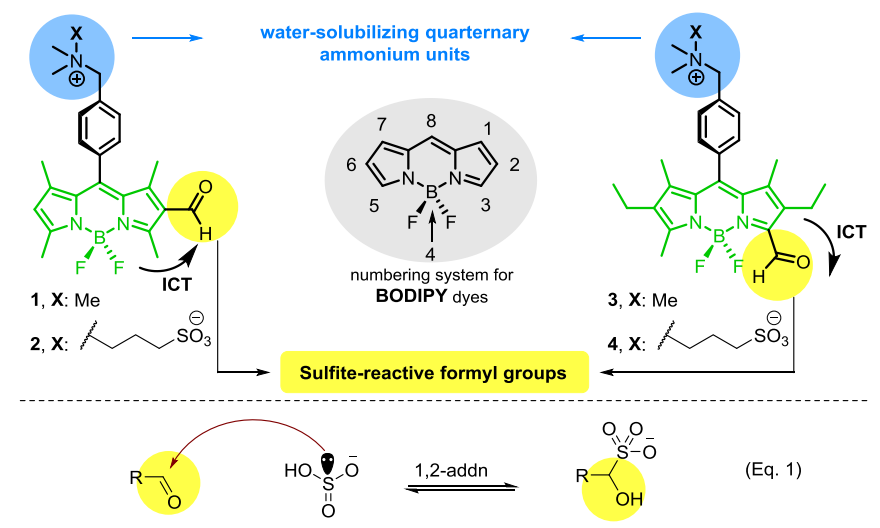

Fig. 1. Design of the sulfite probes. yields (40\% and $48 \%$ respectively). The available 2-position of compound $\mathbf{5}$ was formylated using the Vilsmeier-Haack formylation protocol reported by Jiao and Hao [28].

The formyl functionality was introduced to the 3-position of BODIPY 6 via DDQ-mediated oxidation of an $\alpha$-methyl group, using a method developed by Ziessel and co-workers [29]. We discovered that the use of twelve equivalents of DDQ was essential to obtain compound $\mathbf{8}$ in acceptable purity for the next step. Finally, the benzylic tert-amino groups of the 2- and 3-formylBODIPY dyes ( 7 and 8) were quaternized by treating their concentrated dichloromethane solutions with 10 equiv. of (pseudo)-halides (methyl iodide and 1,3-propanesultone) at room temperature for 2 days. This series of reactions furnished the targeted probe candidates 1-4, the purification of which was achieved by repetitive centrifuging-washing processes.

All of the (zwitter)-ionic compounds 1-4 were soluble in water, thus permitting all spectroscopic studies to be conducted in aqueous buffers. We began our spectroscopic measurements by taking the fluorescence emission spectra of free dyes 1-4 in phosphate buffered saline (PBS; $10 \mathrm{mM}$ ) at physiological $\mathrm{pH}$ (7.4) (see ESI for UV-vis and fluorescence excitation and emission spectra of compounds 1-4). Fig. 2 shows the relative emission behaviour of compounds 1-4, where each is present at equal concentration $(1 \mu \mathrm{M})$. 3-FormylBODIPY 3, among the candidates, lacks background fluorescence and thus was selected as the probe of choice. The others, however, showed significant fluorescence emissions visible to the naked eye (see inset in Fig. 2). Probe 3, once incubated with 1000 equiv. of sulfite for two minutes, starts to fluoresce greenish-yellow at $543 \mathrm{~nm}$ (see ESI). The equilibrium distribution of sulfite species strongly depends on the $\mathrm{pH}$ of the medium (vide supra), and bisulfite addition to probe $\mathbf{3}$ (aldehyde) may also show similar $\mathrm{pH}$-dependency since the reaction is reversible (Eq. 1 in Fig. 1). Therefore, we wanted to explore the $\mathrm{pH}$ dependency of this sensing event. To this end, we screened a $\mathrm{pH}$ range of $4-8$ by altering the $\mathrm{pH}$ in half unit increments (see ESI), and gratifyingly the probe was essentially insensitive to variations in $\mathrm{pH}$ in the absence and presence of $\mathrm{HSO}_{3}^{-} / \mathrm{SO}_{3}^{2-}$ species. Although the sensing reactions equilibrated more rapidly at $\mathrm{pH} \geq 6.0$ (response time $<1 \mathrm{~min}$ ) than those at $\mathrm{pH} \leq 5.5$ (response time $<5 \mathrm{~min}$ ) with no significant difference in the emission profiles, the $\mathrm{pH}$ value was set to 4.5 as it provided higher and more stable emission signals with acceptable response times $(\approx 5 \mathrm{~min})$. Given the strong $\mathrm{pH}$-dependency of some precedent probes, the use of probe 3 would be highly advantageous for applications where $\mathrm{pH}$ independency is required (e.g. some cancer cells are acidic, while some are alkaline). The sensing reaction between probe $\mathbf{3}$ and bisulfites is amenable to HRMS analysis (see ESI), attesting to the 1,2-addition.

To reveal the time-dependency of probe 3 , we recorded the kinetic profiles of the probe against varying amounts of $\mathrm{HSO}_{3}^{-}(0$, 100, 500 and 1000 equiv.). Fig. 2 clearly shows that the sensing reaction equilibrates within five minutes when the dye is at a $5 \mu \mathrm{M}$ concentration.

We also wanted to see to what extent probe $\mathbf{3}$ was selective. Towards this end, a large number of anions, cations, and neutral molecules with potentially interfering or competing natures were tested. The spectral responses of the highly competitive anions and biological thiols are plotted in Fig. 3 (Left).

Probe $3(2 \mu \mathrm{M})$ shows a clear preference for bisulfite among the twenty competing species (100 equiv.) examined; a small yet detectable response to $\mathrm{HS}^{-}$is also observed. Notably, the probe tolerates reactive oxygen species ( $\mathrm{ROS}$ : $\mathrm{HSO}_{5}^{-}, \mathrm{H}_{2} \mathrm{O}_{2}$ ) and reactive sulfur species (RSS: $\mathrm{S}_{2} \mathrm{O}_{3}^{2-}, \mathrm{HSO}_{4}^{-}, \mathrm{HS}^{-},(L)-\mathrm{Cys},(L)-\mathrm{Hcy}, \mathrm{GSH}$ ) as well as nucleophiles $\left(\mathrm{CN}^{-}, \mathrm{NO}_{2}^{-}\right)$with no observable signal change. It also displays no spectral interference to six cations of biological signif- 


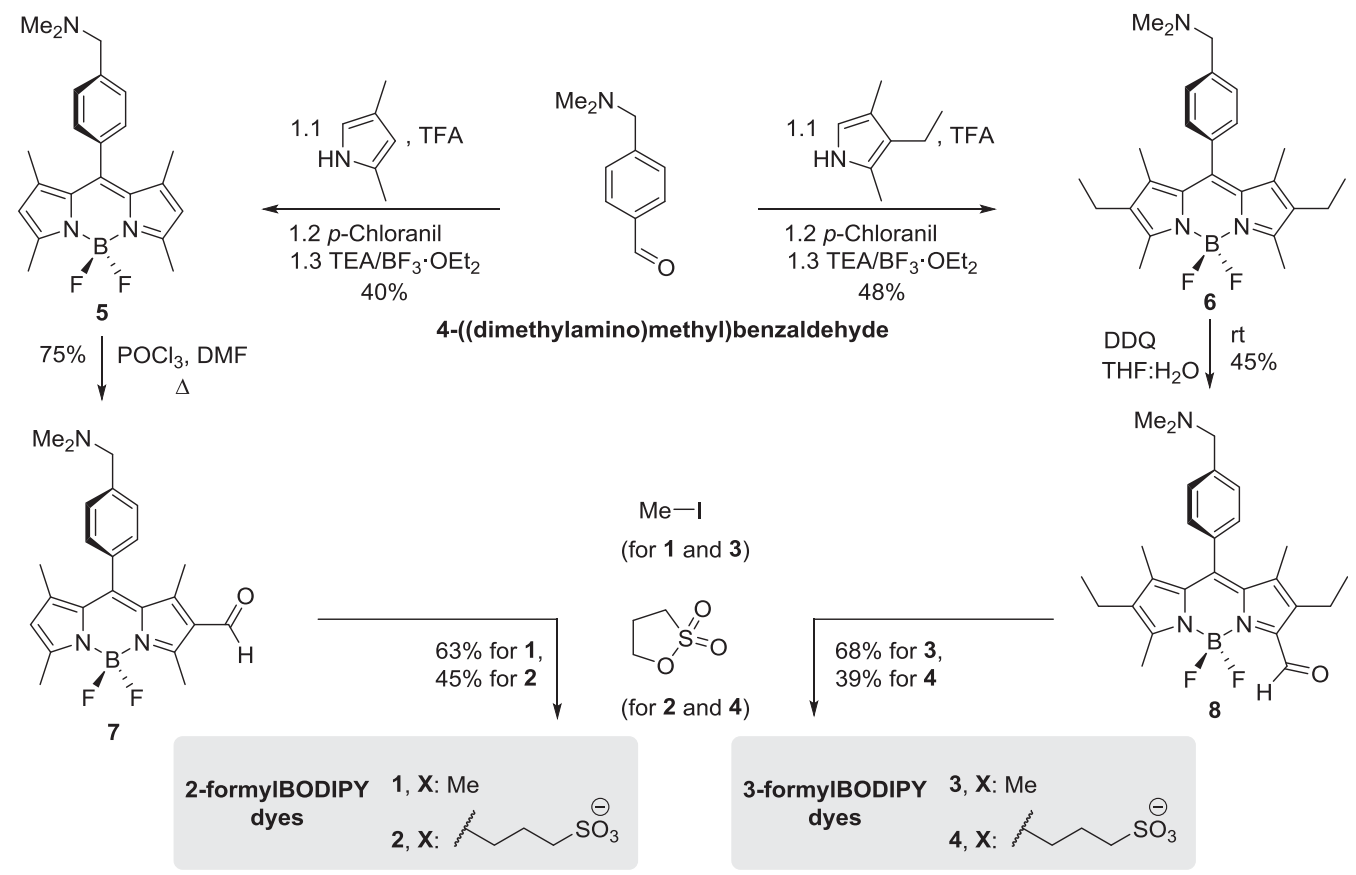

Scheme 1. Synthesis of probes 1-4.
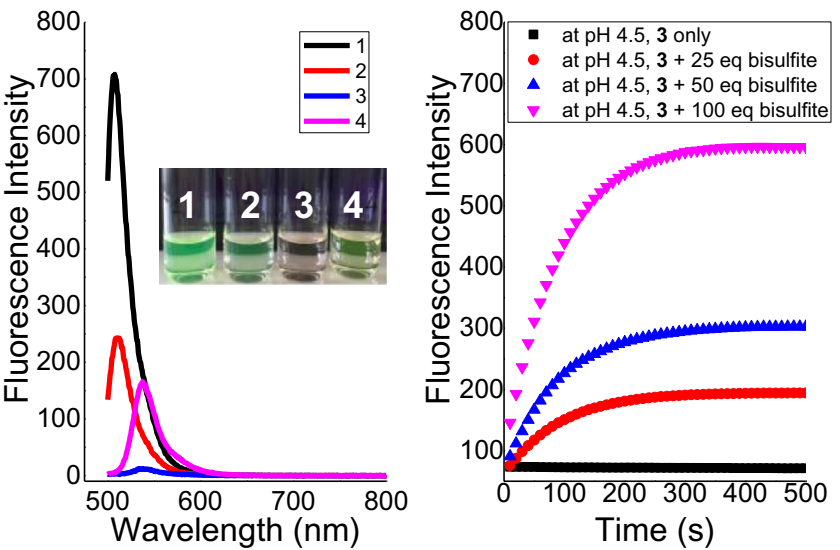

Fig. 2. Left: Fluorescence emission spectra of the probe candidates 1-4 (each $1 \mu \mathrm{M}$ ) in $10 \mathrm{mM}$ PBS $\left(\mathrm{pH}=7.40, \lambda_{\mathrm{ex}} 490 \mathrm{~nm}\right)$. Slit width: $d_{\mathrm{ex}}=5 \mathrm{~nm}, d_{\mathrm{em}}=2.5 \mathrm{~nm}$ Inset: Digital photograph of the solutions under a handheld UV lamp (@ $366 \mathrm{~nm}$ ). Right: Time-dependent fluorescence emission spectra of the probe $3(5 \mu \mathrm{M})$ in the absence and presence of varying amounts of bisulfite in $10 \mathrm{mM}$ acetate buffers $\left(\mathrm{pH}=4.5, \lambda_{\text {ex }}\right.$ $\left.490 \mathrm{~nm}, \lambda_{\mathrm{em}} 543 \mathrm{~nm}\right)$.

icance $\left(\mathrm{Mg}^{2+}, \mathrm{Ca}^{2+}, \mathrm{Zn}^{2+}, \mathrm{Cu}^{2+}, \mathrm{Fe}^{3+}\right.$, and $\left.\mathrm{Hg}^{2+}\right)$, whether by reactions or noncovalent interactions (see ESI).

We were also interested in the fluorescence response of probe 3 to increasing bisulfite concentrations. Remarkably, probe $\mathbf{3}$ responds to increasing bisulfite concentrations in a linear fashion $(10-2000 \mu \mathrm{M})$, which may suggest the quantification of sulfites in food/beverage or biological matrices (see Fig. 3). The limit of detection of probe $\mathbf{3}$ for sensing bisulfite was determined as $9.05 \mu \mathrm{M}$ (see ESI). Literature examples of 2- and 3-formylBODIPY dyes are rare, and they are generally converted to their more reactive derivatives for sensing applications [30]. There are only two reports which make use of 2- and 3-formylBODIPY dyes as fluorogenic probes [31,32]. The groups of Hao and Jiao have shown that 3-formylBODIPY dyes are able to sense reactive biological thiols, cysteine and homocysteine [ $(L)$-Cys and $(L)$-Hcy], however waterinsolubility of the probes requires the use of as much as 50\%
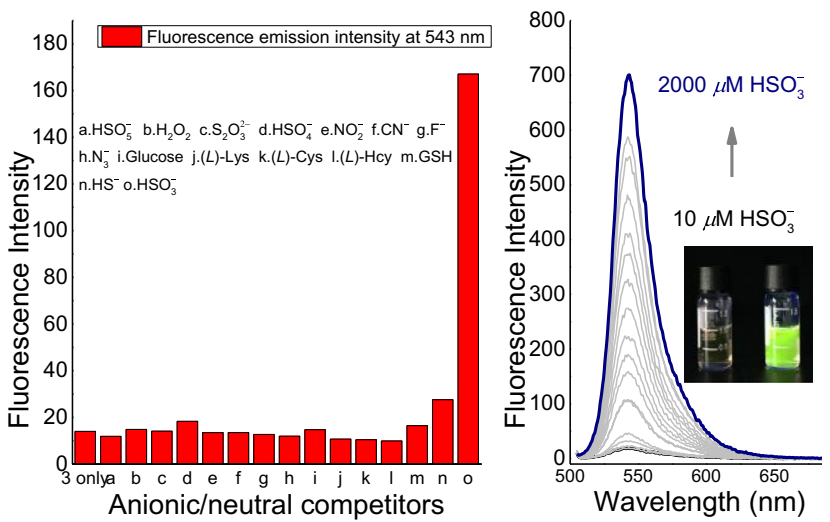

Fig. 3. Left: Fluorescence emission response of probe $3(2 \mu \mathrm{M})$ in the absence and presence of 100 equiv. of bisulfite and other potentially competing anions and neutral molecules. GSH: Glutathione, $(L)$-Hcy: $(L)$-Homocysteine, $(L)$-Cys: $(L)$ Cysteine Right: Fluorescence emission response of probe $3(5 \mu \mathrm{M})$ titrated against increasing amounts of bisulfite $(50-2000 \mu \mathrm{M})$. Inset: Digital photograph of the free dye 3 (left) and dye 3 plus an excess of bisulfite (right) under a handheld UV lamp (@366 nm).

methanol as the solvent [HEPES/MeOH, 1/1 (v/v)], which results in significant initial fluorescence and slow response (60 min) towards Cys and Hcy with 3-5 fold fluorescence intensity enhancement [31]. When compared to the 3-formylBODIPY dyes of Jiao and Hao, probe 3 exhibits enhanced water-solubility, allows sensing applications in $100 \%$ aqueous media and is quenched very well, which renders it highly fluorogenic (up to 38 fold enhancement).

Finally, we examined whether probe 3 would be suitable for applications in live cells. To this end, human lung adenocarcinoma (A549) cells were incubated at $37^{\circ} \mathrm{C}$ first with probe $3(5.0 \mu \mathrm{M})$ for $30 \mathrm{~min}$, then with bisulfite $(500 \mu \mathrm{M})$ for another $30 \mathrm{~min}$. Fluorescence microscopy images (Fig. 4) clearly indicates that probe $\mathbf{3}$ is cell-permeable, and, when incubated alone with cells (panel a), shows no emission suggesting no non-specific binding, and is able 

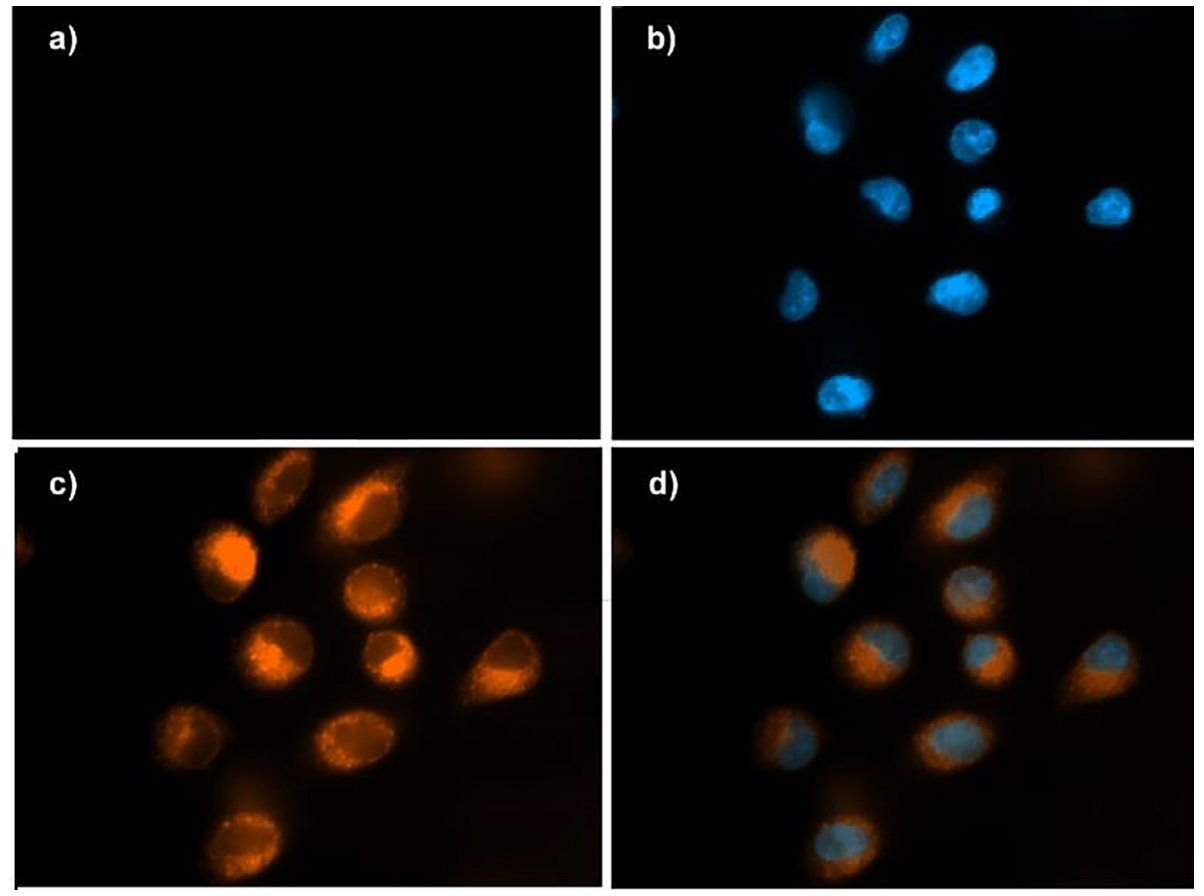

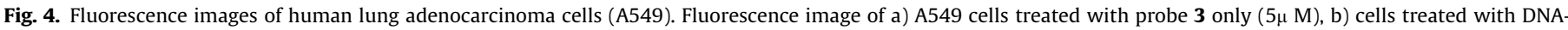

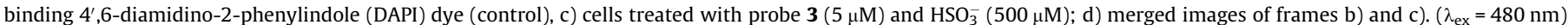

to highlight the cytoplasm of A549 cells in the presence of bisulfites. The probe is nucleus-impermeable as evidenced by nucleus-staining control experiment (panel b-d).

In conclusion, a novel method is reported for the synthesis of BODIPY dyes that are both water-soluble and effectively quenched (fluorescence). Four formyl-attached BODIPY dyes 1-4 bearing quaternary ammonium units which make them water-soluble were synthesised. 2-Formyl dyes (1 and $\mathbf{2}$ ) were highly fluorescent rendering themselves unsuitable for sensing applications. Upon reaction with sulfites, otherwise non-fluorescent probe 3 begins to fluoresce (up to 38 fold) greenish-yellow $\left(\lambda_{\mathrm{em}}=543 \mathrm{~nm}\right.$ ) within a few minutes. Probe 3 shows high specificity for sulfites over a number of competitors with no $\mathrm{pH}$-dependency and works inside cytosol of A549 carcinoma cells, which makes it an interesting probe for (bi)sulfites. Currently, our efforts are directed to determine the metabolic relation of $\mathrm{SO}_{2}$ and biological thiols[17e] for which the design of probe $\mathbf{3}$ is going to be a useful guide.

\section{Acknowledgments}

We are grateful to TÜBITAK (3501 - Career Development Program (CAREER)/114Z806) and BUBAP of Bingöl University (BAP-834-255-2015, BAP-MMF.2016.00.003 and BAP-MMF. 2017.00.002) for granting this study. We thank the Central Laboratory of Bingöl University for housing our research. We are also thankful to Dr. M. Emrullahoğlu, Dr. E. Karakuş and Dr. N. T. Subaşı for their help in taking some spectra.

\section{Appendix A. Supplementary data}

Supplementary data to this article can be found online at https://doi.org/10.1016/j.tetlet.2019.04.039.

\section{References}

[1] a) X. Chen, Y. Zhou, X. Peng, J. Yoon, Chem. Soc. Rev. 39 (2010) 2120; b) H.S. Jung, X. Chen, J.S. Kim, J. Yoon, Chem. Soc. Rev. 42 (2013) 6019; c) C. Yin, F. Huo, J. Zhang, R. Martinez-Manez, Y. Yang, H. Lv, S. Li, Chem. Soc.
Rev. 42 (2013) 6032;

d) H. Peng, W. Chen, Y. Cheng, L. Hakuna, R. Strongin, B. Wand, Sensors 12 (2012) 15907:

e) C.-X. Yin, K.-M. Xiong, F.-J. Hou, J.C. Salamanca, R.M. Strongin, Angew. Chem., Intl. Ed. 56 (2017) 13188.

[2] V.S. Lin, W. Chen, M. Xian, C.J. Chang, Chem. Soc. Rev. 44 (2015) 4596.

[3] Re-evaluation of sulfur dioxide-sulfites (E220-228), EFSA Journal, 2016,14(4) 4438 [151 pp.]

[4] C.S. Ough, E.A. Crowell, J. Food Sci. 52 (1987) 386.

[5] W.H. Yang, E.C. Purchase, Can. Med. Assoc. J. 133 (1985) 865.

[6] M.H. Stipanuk, Annu. Rev. Nutr. 24 (2004) 539.

[7] D. Liu, Y. Huang, D. Bu, A.D. Liu, L. Holmberg, Y. Jia, C. Tang, J. Du, H. Jin, Cell Death Dis. 5 (2014) e1251.

[8] W.G.W. Monier, Analyst 52 (1927) 343.

[9] D. Danton Nygaard, Analytica Chimica Acta 127 (1981) 257.

[10] Z.D.G. Jankovskiene, A. Padarauskas, J. Chromatogr. A 934 (2001) 67.

[11] R.E. Humphrey, W.L. Hinze, W.H. Ward, Anal. Chem. 42 (1970) 698.

[12] G.J. Mohr, Chem. Commun. (2002) 2646.

[13] a) Y. Yang, Q. Zhao, W. Feng, F. Li, Chem. Rev. 113 (2013) 192; b) C.J. Chang, T. Gunnlaugsson, T.D. James, Chem. Soc. Rev. 44 (2015) 4484.

[14] J. Chan, S.C. Dodani, C.J. Chang, Nat. Chem. 4 (2012) 973.

[15] a) H. Tian, J. Qian, Q. Sun, H. Bai, W. Zhang, Anal. Chim. Acta 788 (2013) 165; b) L.E. Santos-Figueroa, C. Gimenez, A. Agostini, E. Aznar, M.D. Marcos, F Sancenon, R. Martinez-Manez, P. Amoros, Angew. Chem., Int. Ed. 52 (2013) 13712;

c) Y.Q. Sun, J. Liu, J. Zhang, T. Yang, W. Guo, Chem. Commun. 49 (2013) 2637;

d) M.Y. Wu, K. Li, C.Y. Li, J.T. Hou, X.Q. Yu, Chem. Commun. 50 (2014) 183; e) L. Tan, W. Lin, S. Zhu, L. Yuan, K. Zheng, Org. Biomol. Chem. 12 (2014) 4637; f) L. Zhu, J. Xu, Z. Sun, B. Fu, C. Qin, L. Zeng, X. Hu, Chem. Commun. 51 (2015) 1154;

g) Y. Liu, K. Li, M.Y. Wu, Y.H. Liu, Y.M. Xie, X.Q. Yu, Chem. Commun. 51 (2015) 10236;

h) Y. Liu, K. Li, K.X. Xie, L.L. Li, K.K. Yu, X. Wang, X.O. Yu, Chem. Commun. 52 (2016) 3430;

i) D.P. Li, Z.Y. Wang, X.J. Cao, J. Cui, X. Wang, H.Z. Cui, J.Y. Miao, B.X. Zhao, Chem. Commun. 52 (2016) 2760;

k) S. Samanta, P. Dey, A. Ramesh, G. Das, Chem. Commun. 52 (2016) 10381; l) J. Yang, K. Li, J.-T. Hou, L.-L. Li, C.-Y. Lu, Y.-M. Xie, X. Wang, X.-Q. Yu, ACS Sens. 1 (2016) 166;

m) D.-P. Li, Z.-Y. Wang, J. Cui, X. Wang, J.-Y. Miao, B.-X. Zhao, Sci. Rep. 7 (2017) 45294;

n) S. Paul, K. Ghoshal, M. Bhattacharyya, D.K. Maiti, ACS Omega 2 (2017) 8633; o) M.-F. Huang, L.-N. Chen, J.-Y. Ning, W.-L. Wu, X.-D. He, J.-Y. Miao, B.-X. Zhao, Sens. Actuators, B 261 (2018) 196;

p) Y. Zhou, F. Zeng, Y. Liu, M. Li, S. Xiao, N. Zhang, K. Zheng, Tetrahedron Lett. 59 (2018) 3253;

o) J. Xu, D.-J. Zheng, M.-M. Su, Y.-C. Chen, Q.-C. Jiao, Y.-S. Yang, H.-L. Zhu, Org. Biomol. Chem. 16 (2018) 8318. 
[16] a) M.G. Choi, J. Hwang, S. Eor, S. Chang, Org. Lett. 12 (2010) 5624;

b) X. Gu, C. Liu, Y.C. Zhu, Y.Z. Zhu, J. Agric. Food. Chem. 59 (2011) 11935;

c) X. Ma, C. Liu, Q. Shan, G. Wei, D. Wei, Y. Du, Sens. Actuators, B 188 (2013) 1196;

d) C. Yu, M. Luo, F. Zeng, S. Wu, Anal. Methods 4 (2012) 2638.

[17] a) X.-F. Yang, M. Zhao, G. Wang, Sens. Actuators, B 152 (2011) 8;

b) Y. Yang, F. Huo, J. Zhang, Z. Xie, J. Chao, C. Yin, H. Tong, D. Liu, S. Jin, F. Cheng,

X. Yan, Sens. Actuators, B 166 (2012) 665;

c) Y.Q. Sun, P. Wang, J. Liu, J. Zhang, W. Guo, Analyst 137 (2012) 3430;

d) C. Yu, M. Luo, F. Zeng, S. Wu, Anal. Methods (2012) 4;

e) Y. Yue, F. Huo, P. Ning, Y. Zhang, J. Chao, X. Meng, C. Yin, J. Am. Chem. Soc. 139 (2017) 3181;

f) G. Chen, W. Zhou, C. Zhao, Y. Liu, T. Chen, Y. Li, B. Tang, Anal. Chem. 90 (2018) 12442.

[18] a) Y. Sun, C. Zhong, R. Gong, H. Mu, E. Fu, J. Org. Chem. 74 (2009) 7943;

b) G. Li, Y. Chen, J. Wang, Q. Lin, J. Zhao, L. Ji, H. Chao, Chem. Sci. (2013) 4;

c) J. Chao, Y. Zhang, H. Wang, Y. Zhang, F. Huo, C. Yin, L. Qin, Y. Wang, Sens. Actuators, B 188 (2013) 200;

d) C. Wang, S. Feng, L. Wu, S. Yan, C. Zhong, P. Guo, R. Huang, X. Weng, X. Zhou, Sens. Actuators, B 190 (2014) 792;

e) W. Chen, Q. Fang, D. Yang, H. Zhang, X. Song, J. Foley, Anal. Chem. 87 (2015) 609;

f) W. Xu, C.L. Teoh, J. Peng, D. Su, L. Yuan, Y.-T. Chang, Biomaterials 56 (2015) 1 ;

g) S. Yang, X. Wen, X. Yang, Y. Li, C. Guo, Y. Zhou, H. Li, R. Yang, Anal. Chem. 90 (2018) 14514.

[19] a) M. Isik, T. Ozdemir, I.S. Turan, S. Kolemen, E.U. Akkaya, Org. Lett. 15 (2013) 216;

b) M. Işıı, R. Guliyev, S. Kolemen, Y. Altay, B. Senturk, T. Tekinay, E.U. Akkaya, Org. Lett. 16 (2014) 3260;

c) S. Kolemen, M. Işı1k, G.M. Kim, D. Kim, H. Geng, M. Buyuktemiz, T. Karatas, X. F. Zhang, Y. Dede, J. Yoon, E.U. Akkaya, Angew. Chem., Int. Ed. 54 (2015) 5340

[20] a) A. Loudet, K. Burgess, Chem. Rev. 107 (2007) 4891;

b) G. Ulrich, R. Ziessel, A. Harriman, Angew. Chem., Int. Ed. 47 (2008) 1184;

c) N. Boens, V. Leen, W. Dehaen, Chem. Soc. Rev. 41 (2012) 1130.

[21] a) O.A. Bozdemir, R. Guliyev, O. Buyukcakir, S. Selcuk, S. Kolemen, G. Gulseren,

T. Nalbantoglu, H. Boyaci, E.U. Akkaya, J. Am. Chem. Soc. 132 (2010) 8029;

b) H. Sunahara, Y. Urano, H. Kojima, T. Nagano, J. Am. Chem. Soc. 129 (2007) 5597.

[22] a) M. Baruah, W.W. Qin, R. Vallee, D. Beljonne, T. Rohand, W. Dehaen, N. Boens, Org. Lett. 7 (2005) 4377;

b) A. Coskun, E.U. Akkaya, J. Am. Chem. Soc. 127 (2005) 10464; c) T. Matsumoto, Y. Urano, T. Shoda, H. Kojima, T. Nagano, Org. Lett. 9 (2007) 3375;

d) S. Yin, V. Leen, S.V. Snick, N. Boens, W. Dehaen, Chem. Commun. 46 (2010) 6329;

e) B.W. Michel, A.R. Lippert, C.J. Chang, J. Am. Chem. Soc. 134 (2012) 15668; f) J. Shao, H. Sun, H. Guo, S. Ji, J. Zhao, W. Wu, X. Yuan, C. Zhang, T.D. James, Chem. Sci. 3 (2012) 1049.

[23] a) S. Erten-Ela, M.D. Yilmaz, B. Icli, Y. Dede, S. Icli, E.U. Akkaya, Org. Lett. 10 (2008) 3299;

b) T. Bura, N. Leclerc, S. Fall, P. Lévêque, T. Heiser, P. Retailleau, S. Rihn, A. Mirloup, R. Ziessel, J. Am. Chem. Soc. 134 (2012) 17404.

[24] a) T. Yogo, Y. Urano, F. Ishitsuka, T. Nagano, J. Am. Chem. Soc. 127 (2005) 12162;

b) Y. Cakmak et al., Angew. Chem., Int. Ed. 50 (2011) 11937;

c) M. Üçüncü, E. Karakuş, E.K. Demirci, M. Sayar, S. Dartar, M. Emrullahoğlu, Org. Lett. 19 (2017) 2522.

[25] a) Y. Ueno, J. Jose, A. Loudet, C. Pérez-Bolívar, P. Anzenbacher Jr., K. Burgess, J. Am. Chem. Soc. 133 (2011) 51;

b) R. Ziessel, G. Ulrich, A. Haefele, A. Harriman, J. Am. Chem. Soc. 135 (2013) 11330.

[26] a) S. Atilgan, Z. Ekmekci, A.L. Dogan, D. Guc, E.U. Akkaya, Chem. Commun. (2006) 4398;

b) L. Li, J. Han, B. Nguyen, K. Burgess, J. Org. Chem. 73 (2008) 1963;

c) S.L. Niu, G. Ulrich, R. Ziessel, A. Kiss, P.-Y. Renard, A. Romieu, Org. Lett. 11 (2009) 2049;

d) S. Zhu, J. Zhang, G. Vegesna, F.T. Luo, S.A. Green, H. Liu, Org. Lett. 13 (2011) 438;

e) T. Bura, R. Ziessel, Org. Lett. 13 (2011) 3072;

f) S. Niu, C. Massif, G. Ulrich, P.Y. Renard, A. Romieu, R. Ziessel, Chem.-Eur. J. 18 (2012) 7229;

g) G.K. Vegesna, S.R. Sripathi, J. Zhang, S. Zhu, W. He, F.-T. Luo, W.J. Jahng, M. Frost, H. Liu, ACS Appl. Mater. Interfaces 5 (2013) 4107.

[27] B. Wang D. Chu PCT Int. Appl 2372011 pp. CODEN:PIXXD2, W02011130661.

[28] L. Jiao, C. Yu, J. Li, Z. Wang, M. Wu, E. Hao, J. Org. Chem. 74 (2009) 7525.

[29] A. Haefele, C. Zedde, P. Retailleau, G. Ulrich, R. Ziessel, Org. Lett. 12 (2010) 1672.

[30] a) M. Emrullahoğlu, M. Üçüncü, E. Karakuş, Chem. Commun. 49 (2013) 7836; b) L.A. Juárez, A.M. Costero, M. Parra, P. Gaviña, S. Gil, Chem. Eur. J. 22 (2016) 8448.

[31] a) Q. Wu, Y. Wu, M. Zhang, C. Yu, E. Hao, L. Jiao, J. Porphyrins Phthalocyanines 20 (2016) 444

[32] a) Q. Wu, J. Zhou, Y. Wu, C. Yu, E. Hao, L. Jiao, New J. Chem. 40 (2016) 1387. 